\title{
Forestry in a Mountain Environment
}

\author{
HANS WAELTI
}

\author{
British Columbia Forest Service \\ Victoria, British Columbia
}

\begin{abstract}
The importance of mountain forests in several countries is shown and the environmental role of geomorphologic processes, particularly the role of rare events and their significance for forestry, demonstrated. Planning of forestry operations must give recognition to these factors, if long lasting erosion problems are to be avoided. The development of environmentally acceptable and efficient logging systems and silvicultural practices for steep slopes is urgently required if the full potential of mountain forests is to be realized.
\end{abstract}

\section{Résumé}

L'importance des forêts en montagne dans plusieurs pays est mentionnée et le rôle sur l'environnement de processus géomorphologiques, surtout le rôle d'événements rares et de leur signification pour la forestrie sont démontrés. La planification des opérations forestières doit tenir compte de ces facteurs pour éviter des problèmes d'érosion de longue durée. II est pressant de développer des systèmes d'exploitation forestière des pentes abruptes qui soient efficaces et qui soient acceptables pour l'environnement pour réaliser le plein potentiel des forêts en montagne.

\section{Introduction}

In many regions of the world, such as Alpine Europe, the Western Americas, Japan and New Zealand, mountain forests play a dominant environmental and economic role. Their characteristics and the consequences that may result from indiscriminate forest harvesting operations, are often not adquately understood and considered in management plans. Only when noticeable increases in erosion, floods, and other damaging events have occurred, do people become concerned and demand remedial action. Then it is often too late and such measures that are taken to ameliorate deforested sites and eroding slopes, to stabilize creeks and to prevent snow from avalanching into valley bottoms are extremely costly and may take decades to become effective.

Foresters working in mountainous regions therefore must have a thorough understanding of the mountain environment and the forces that are significant these areas and different from lowland situations if costly environmental mistakes are to be avoided.

\section{Significance of Mountain Forests}

Steep slopes are a prime characteristic of mountains. Stratification of forest land by slope classes therefore gives a good indication of the significant in these areas and different from lowarea.

Table 1. Distribution of forest area by slope classes for Switzerland, Norway and Japan

\begin{tabular}{|c|c|c|c|c|c|}
\hline \multirow{3}{*}{$\begin{array}{l}\text { Country } \\
\text { Switzerland }^{1}\end{array}$} & \multirow{3}{*}{$\begin{array}{c}\begin{array}{c}\text { Slope } \\
\%\end{array} \\
0-20 \\
20-40 \\
40-60 \\
60-80 \\
80-100 \\
\text { over } 100\end{array}$} & \multicolumn{4}{|c|}{$\%$ of forested area } \\
\hline & & \multicolumn{2}{|c|}{ whole country } & \multicolumn{2}{|c|}{ specific areas } \\
\hline & & $\begin{array}{r}24 \\
27 \\
24 \\
17 \\
5 \\
3\end{array}$ & & $\begin{array}{c}\text { Alps on } \\
7 \\
23 \\
34 \\
25 \\
6 \\
5\end{array}$ & \\
\hline \multirow[t]{3}{*}{ Norway $^{2}$} & $\begin{array}{r}0-10 \\
10=20 \\
20=33 \\
33-50 \\
\text { over } 50\end{array}$ & $\begin{array}{r}30 \\
37 \\
22 \\
8 \\
3\end{array}$ & & & \\
\hline & & \multicolumn{4}{|c|}{ by elevation zones } \\
\hline & & & $\begin{array}{c}0-400 \\
\mathrm{~m}\end{array}$ & $\underset{\mathrm{m}}{400-1000}$ & $\begin{array}{c}\text { over } \\
1000 \\
\text { m }\end{array}$ \\
\hline Japan $^{3}$ & $\begin{array}{r}0-27 \\
27-58 \\
\text { over } 58\end{array}$ & $\begin{array}{l}30 \\
42 \\
28\end{array}$ & $\begin{array}{l}40 \\
42 \\
18\end{array}$ & $\begin{array}{l}21 \\
43 \\
36\end{array}$ & $\begin{array}{l}18 \\
36 \\
46\end{array}$ \\
\hline
\end{tabular}

${ }^{1}$ Ott 1972. ${ }^{2}$ Samset 1973. ${ }^{3}$ Kamiizaka 1975 


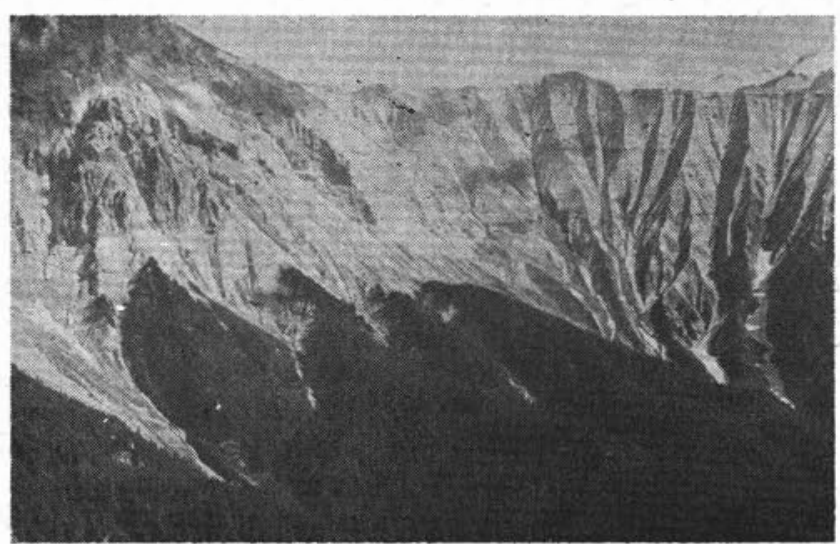

Figure 1. Bare, heavily gullied mountainside. Under heavy precipitation runoff will be very rapid with a high rate of erosion. Forest cover is only found on stable slopes and ridges. While the forest helps to stabilize creek beds in the zone below bare soil and rocks, the main source of runoff and sediment is from the area above the forested zone.

In British Columbia (Canada), the Forest Inventory Division of the B.C. Forest Service estimates that about half of all forest stands are situated on slopes of over $40 \%$. This portion could be considerably higher in the highly productive coastal stands and in the interior mountain ranges.

Measurements made on 1:50,000 topographic maps with 100 -foot $(30.5 \mathrm{~m})$ contours for the Slocan Public Sustained Yield Unit in the Selkirk Mountains in south-eastern British Columbia gave the following results:

\begin{tabular}{lrc}
$\begin{array}{l}\text { Slope } \\
\text { range }\end{array}$ & forest area & $\%$ of area \\
\hline $0-30 \%$ & 56,000 acres $(22,600 \mathrm{ha})$ & 21 \\
$30-60 \%$ & 90,000 acres $(36,400 \mathrm{ha})$ & 35 \\
over $60 \%$ & 114,000 acres $(46,000 \mathrm{ha})$ & 44
\end{tabular}

Similar results undoubtedly could be obtained for other mountainous regions in British Columbia.

\section{Mountain Geomorphology}

If the special role of forests in a mountain environment is to be understood, it is first necessary to understand the geomorphology of mountains and the erosion processes that incessantly wear down peaks and slopes and the factors that determine their magnitude. Mountains and their geology and geomorphology are directly linked with the lower, inhabited areas of drainage basins. Events taking place in the mountains may have far reaching downstream effects and the consequences of floods that originate in uninhabited high elevations may not become disastrous until the flood waves reach the developed river flats at lower levels. The beneficial influences of the mountain forests therefore are significant not only for the people living in the mountain valleys themselves, but also for the people living in those lower portions of drainages that are outside the mountain topography.
Mountain geomorphology is characterized by high relief, steep slopes, local climates varying with altitude, and a generally high rate of erosion (Hewitt 1972).

The rate of erosion is primarily dependent on rock or soil type and climate; the interaction of texture, composition and compactness of the material with precipitation and temperature regimes being more important than topographic relief (Fig. 1). Sedimentary rocks, generally erode faster than igneous rocks and the weathering products of fine grained rocks, in particular, tend to produce soils with a high erosion rate (Zeller 1972). In British Columbia one observes a generally higher erosion hazard in the sedimentary rocks of the Rocky Mountains than in the igneous rocks of the Coast Range, despite the much higher precipitations in the latter area.

At altitudes of eternal snow and ice, glaciers appear to be the largest producers of erosional debris. They are outside the consequences of human land use and their behavior is thus influenced by climatic variations only. At lower elevations, avalanches, rock slides, mud-flows and other rapid mass-movements are overwhelmingly important as producers of erosional debris. Some lowland soils and topographies also represent high erosion systems, but in the overall picture the vigor and frequency of erosion is generally highest in mountain areas.

While geology and geomorphology provide the setting, an understanding of the various mass transportation processes is equally important before the role of the forest can be brought into focus. Water is the single most important agent of erosion and sediment transport, and an appreciation of the behavior of mountain streams is essential for understanding the effect of forests on the hydrology of mountain valleys.

While space does not permit full discussion of the hydraulics of mountain streams, the relationship between stream gradient, water volume and bed material is, in simple terms, that over boulders and solid rock gradients are generally steep, and over fine grained and soft material gradients are relatively flat. In terms of erosion this means that a stream tends to rub hard against hard bed material and lightly against soft bed material. Also, as a general rule, the size of a creek channel will accommodate the average maximum water volume (Fig. 2) If in a given channel the amount of water is increased, the velocity of the flow increases which in turn results in a greater erosional force (the water rubs harder against the channel) as well as in an increased capacity to transport material. With the variations in width, gradient, and alignment normally found along natural creek beds a continuous process of erosion and deposition takes place all along a stream. Mountain streams are generally young and their rate of erosion and sediment transport high and fluctuating. Their behavior is not so much characterized by the average flow as by events that occur at infrequent intervals. 
Large or severe forest fires must also be classified as rare events and there are many examples to show that watersheds ravaged by fire took a long time to recover (Fig. 3). Slash burning that results in exposure of large areas of mineral soil, and particularly in unconsolidated fine textured material, poses the same risk in regard to rare events.

When making plans for forest operations in mountain areas, the role and effect of rare events must be recognized and considered; their very existence and the far reaching consequences they may have make it important that operations are planned with care and due recognition of extremes, and that any activities that may reduce resistance of a drainage to withstand extremes are evaluated carefully.

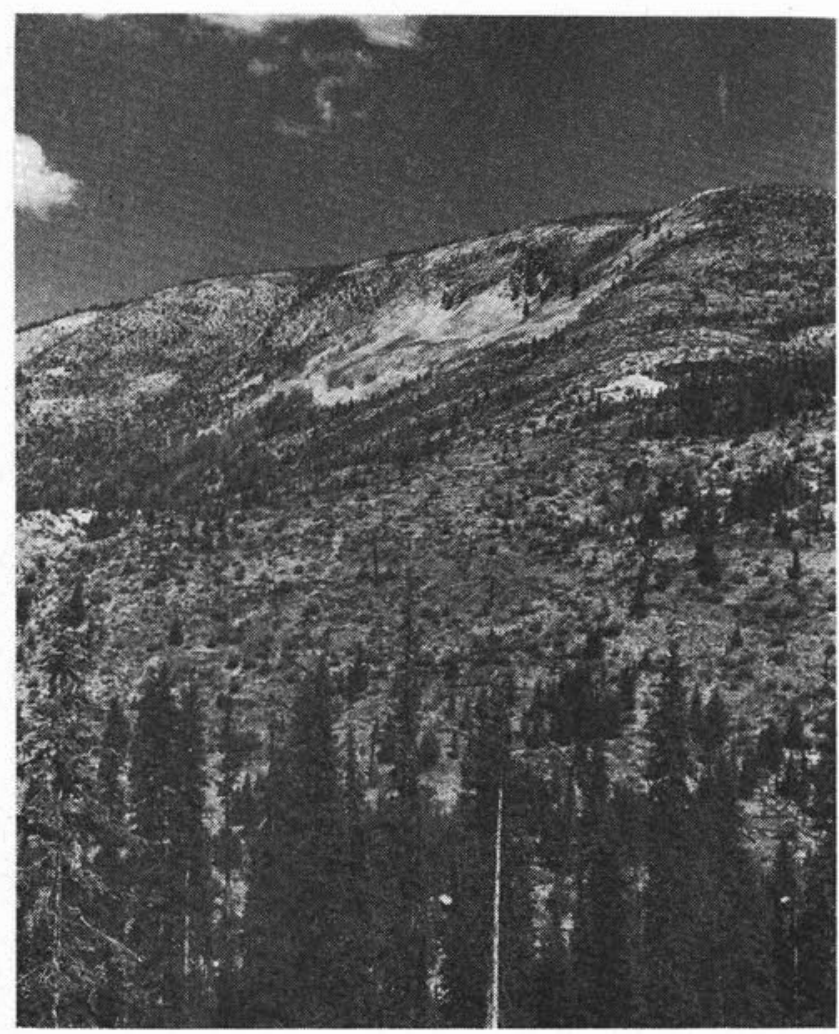

Figure 3. Mountainside ravaged by an extensive forest fire While some vegetation and tree growth has come back, much of the burned off forest litter has not yet re-formed, and runoff from heavy rainstorms will be rapid.

\section{Role of the Forest}

Forests are an integral part of most mountain environments. Their preservation and management makes it possible in many areas for people to live in alpine valleys. Where forests have been wilfully destroyed, mountainous areas have become less attractive and safe for human settlement, and disastrous rare events have become more frequent and more destructive than they were before. This role of the mountain forest may be difficult to understand in areas where forests are still seemingly endless; but the examples provided in old world regions speak for them- selves. The beneficial role of the forest on runoff and erosion appears to be particularly sensitive in dry climates, the Mediterranean Region being a good example of this.

A vigorous forest stand protects the mineral soil from erosion and equalizes runoff more effectively than any other ground cover. This function alone, and especially when related to the significance of rare events, makes the use of appropriate forest management techniques in mountain areas of paramount importance.

The beneficial effect on runoff and stream sediment volumes of a forest stand in contrast to grass cover was first demonstrated by Engler (1919) in two drainages in the pre-Alps of Switzerland. Whereas little surface runoff is present in humus-rich alpine forests, surface flow during heavy precipitation may become significant in grass cover, after forest fires or some forms of logging.

Another important feature of the forest in boreal and in mountainous areas is that it retards the melting of the snow cover and thus effectively lengthens the spring runoff period. In many high mountain areas forest stands also prevent the forming of avalanches. This function is very significant in inhabited alpine valleys and for the protection of transportation routes. The concept of protection forests in the European Alps stems mainly from this function. On smooth, uniform slopes of over about $60 \%$, a dense forest stand is the best "structure" to keep the snow in place. If through extensive logging or overgrazing by domestic and wild animals the close forest stand is opened up, increased avalanche activity may result, destroying more and more trees and ever more favorable conditions for snow slides are created.

Of special interest is the timberline, the zone where due to climate and geomorphologic factors the closed forest dissolves into a scrub zone, or in some situations, ends abruptly. Whereas the climate is the main factor determining the altitude of the timberline, this is often modified by geomorphologic features.

Examples of depressed timberline due to geomorphologic events are: avalanche couloirs, valley glaciers, talus slopes, stone fall areas, slab avalanches with running out zone in the timberline, and unstable and continuously eroding slopes and basins.

If the timber is removed completely by clearcut logging from areas where the forest significantly retards geomorphologic processes such as mass movements and avalanching, these may then become the dominant features. Should this occur it may not be possible to restore the forest cover except through very costly measures.

While this paper deals mainly with critical events and critical sites, many steep areas are quite stable and nature has an extensive ability to recover from destruction and disaster. After all, over its natural range of occurrence, the forest is the most competitive vegetation type. 


\section{Management and Harvest of Mountain Forests}

Moderation of runoff and erosion is one of the main functions of forests in steep topography. Management and harvest must ensure that this environmental benefit is maintained and possibly enhanced. At the same time it must be realized that some soils and topographies have a high natural rate of erosion and that leaving forests in their pristine state does not mean that disastrous events will not occur. In some combinations of soils, geology and climate, the catastrophe threshold will be reached with much greater frequency than in others. Particular attention therefore must be paid to sensitive areas, such as forest stands on highly erodible soils, slide areas, high elevation forests and stands on smooth steep slopes where the forest effectively keeps the snow in place, that is care in any area where indiscriminate logging or other destruction of the forest may jeopardize its beneficial downstream effects. It is important that these areas be recognized at the inventory and planning stage.

In mountainous regions where forestry is well deceloped, criteria and data for recognition of environmentally sensitive areas are available; such data ore often lacking in regions or countries where development of the forest resource is just beginning. Yet it is particularly in these areas, that much future damage and costs could be avoided through prudent planning, recognition of all areas sensitive to erosion, and application of appropriate management restrictions.

Proceeding from the premise that the ultimate objective of forest management planning is to bring about orderly harvest of the timebr ("orderly" in this context meaning in recognition of all environmental constraints while at the same time providing for economically viable forestry operations), the selection of appropriate harvesting and silvicultural systems becomes of paramount importance. (Fig. 4).

Forest operations in mountainous terrain must contend with difficult and often widely varying local conditions. Costs tend to be higher than in flat terrain and silvicultural restrictions more severe. While environmental and silvicultural criteria must take precedence over the goal of minimizing logging costs, the importance of mountain forests to national or regional economies demands that the proper balance between the two countervailing forces be sought and found. This means that logging engineers, silviculturists, hydrologists, pedologists, and others must work together if the objective of profitable harvesting without damage to the environment is to be achieved.

This aim can only be reached through thorough and long term planning. In this process the first step will be a resource inventory to provide information on: forest volumes, species and the ecology of the area; geomorphology, soils and hydrology; topography; other resources such as fish, wildlife, recreation; existing developments such

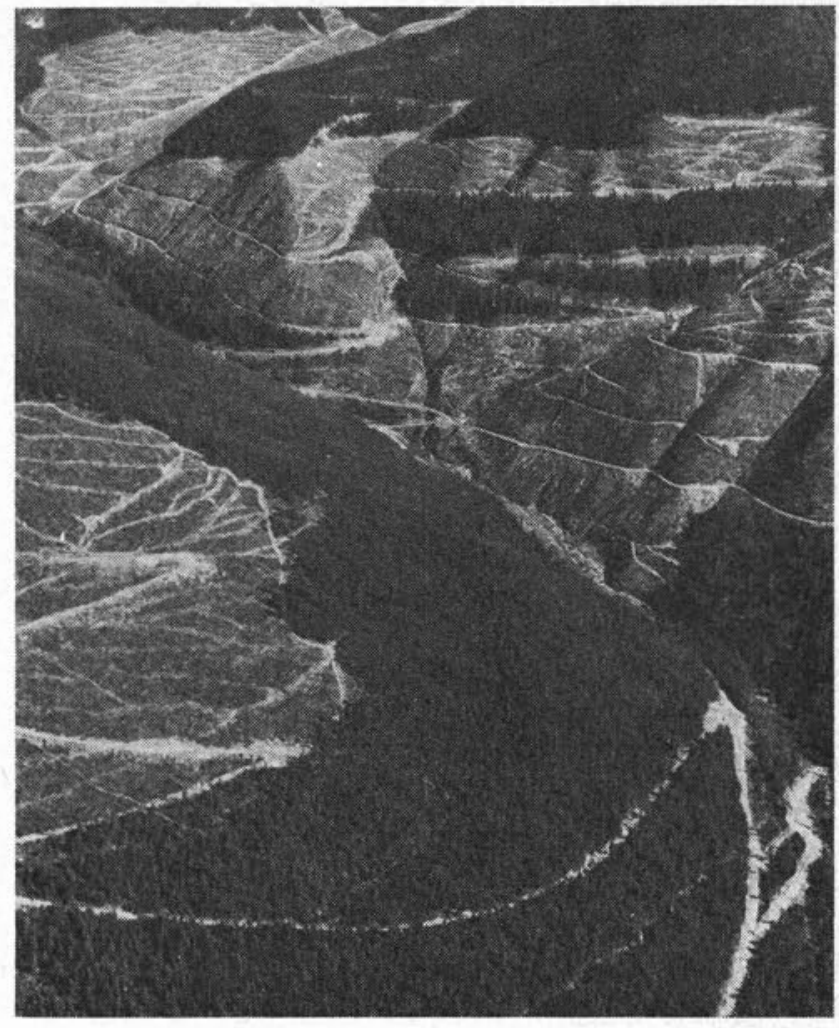

Figure 4. Is this type of logging pattern compatible with environmentally sound forest management?

as roads, settlements, cultural resources; and climate, particularly precipitation regime.

The second step is to delineate environmentally critical areas, such as: unstable soils and soils with severe erosion hazard when disturbed; forest areas significant for the prevention of avalanches; forests areas significant for the moderation of runoff in watersheds and protection of streams; forest stands on sites difficult to regenerate, such as extreme sites, high elevation forests, etc.; forest areas significant for wildlife, recreation, and scenic values. Delineation of these areas will make use of the inventory information and its interpretation. The use of airphoto interpretation techniques can greatly reduce field work (Waelti 1970).

The next step will be the selection of logging systems and the necessary road networks. Recognition must be given to silvicultural systems and the regeneration methods they involve. The volume that can be extracted in a given harvesting pass has a profound effect on the economics of logging, the success of regeneration, and environmental influences. In mountain topography particularly, the high costs of road construction and felling and yarding tend to promote large cuts while environmental and silvicultural criteria may indicate light to moderate interventions.

The rough and steep slopes of mountains make mechanization of harvesting much more difficult than in flat to gently sloping terrain. The development of mechanized and efficient logging systems for different mountain conditions, forest stands and cutting patterns, and which meet the require- 
ments of site protection is a primary challenge to engineers and equipment manufacturers.

The question of the maximum tolerable size of clear cut areas, and the portion of a watershed that may be in a clearcut state at any one time, is being discussed vigorously in British Columbia. As a general principle the area cut should be small enough so that any environmental ill effect does not grow beyond the area cut and its immediate neighbourhood, and that removal of timber should not result in site degradation. It is particularly important to avoid the type of disturbance that will lower the area's ability to withstand rare events.

The development of terrain classification systems, operational characteristics and constraints of various logging systems, silvicultural systems for different sites and forests types, as pointed out by the Krasnodar Symposium on Forest Operations in Mountainous Regions (ECE, FAO) is urgent, and a prerequisite to the planning of forest operations that are both economically viable and environmentally acceptable.

If mountain forests are to be managed for their fullest social benefits and in recognition of all their inherent values and functions, then a thorough understanding of the mountain environment is a prerequisite. This requires not only multi-disciplinary knowledge, but above all a feeling and respect for the mountain landscape and the role of rare events.

\section{Acknowledgments}

Critical review of the manuscript by Dr. P.G. Haddock, Faculty of Forestry and Dr. O. Slay- maker, Department of Geography, both at the University of British Columbia, and Mr. J. Zeller of the Swiss Federal Forestry Research Institute is gratefully acknowledged.

\section{References}

ECE, FAO. 1971. Symposium on forest operations in mountainous regions. Krasnodar (USSR).

Engler, A. 1919. Einfluss des Waldes auf den Stand der Gewässer Eidg. Anst. Forstl. Versuchswesen. Vol. XII.

Froehlich, H. A. 1973. Natural and man-caused slash in headwater streams. Logging Handbook, Pac. Logg. Cong., Portland, Ore. $9 \mathrm{p}$.

Hewitt, K. 1972. The mountain environment and geomorphic process, p. 17-34. In Slaymaker and McPherson (eds.) Mountain geomorphology. Vancouver.

Kamiizaka, M. 1975. Dept. of Forestry, Univ. of Tokyo. Personal communication.

Leopold, L. B., M. G. Wolman, and J. P. Miller, 1964. Fluvial processes in geomorphology. W. H. Freeman and Company, San Francisco. 522 p.

O'Loughlin, C. L. 1972. A preliminary study of landslides in the Coast Mountains of southwest British Columbia, p. 101-111. In Slaymaker and McPherson (eds.) Mountain geomorphology. Vancouver.

Ott, Ernst. 1972. Erhebungen über den gegenwärtigen Zustand des Schweizer Waldes als Grundlage waldbaulicher Zielsetzungen. Mitt. Schweiz. Anst. Forstl. Versuchswesen. Vol. 48, No. 1, 193 p.

Russel, S. O. 1972. Behaviour of steep creeks in a large flood, p. 223-228. In Slaymaker and McPherson (eds.) Mountain geomorphology. Vancouver.

Samset, I. 1973. Forestry operations in a dynamic production forestry. Univ. of British Columbia, H. R. MacMillan Lectureship in Forestry.

Waelti, H. 1970. Forest road planning. Photogr. Engrg. 34: 246-252.

Zeller, J. 1972. Beitrag zur Wildbachgeographie der Schweiz. Schweiz Zeitschrift f. Forstwesen 94: 767-774.
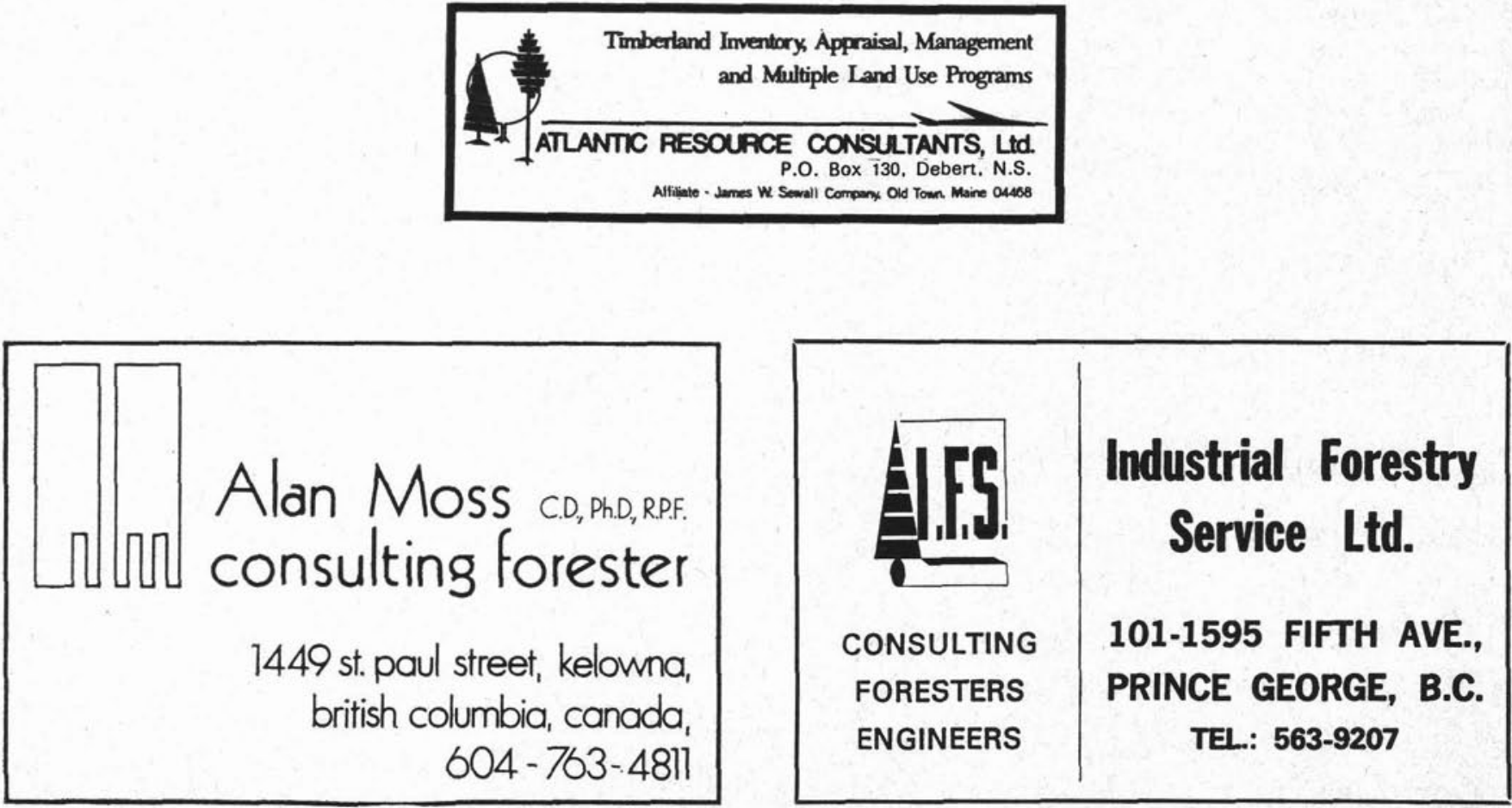